\title{
Research on the maceral characteristics of Shenhua coal and efficient and directional direct coal liquefaction technology
}

\author{
Geping Shu $\cdot$ Yuzhuo Zhang
}

Received: 1 December 2013/Revised: 10 January 2014/ Accepted: 13 January 2014/Published online: 12 September 2014

(C) The Author(s) 2014. This article is published with open access at Springerlink.com

\begin{abstract}
In this research, molecular structure models were developed respectively for Shenhua coal vitrinite concentrates (SDV) and inertinite concentrates (SDI), on the basis of information on constitutional unit of Shenhau coal and elemental analysis results obtained from ${ }^{13} \mathrm{C}$-NMR analysis characterization, FTIR analysis characterization, X-ray diffraction XRD and XPS analysis characterization. It can be observed from characterization data and molecular structure models that the structure of SDV and SDI is dominated by aromatic hydrocarbon, with aromaticity of SDI higher than that of SDV; SDV mainly consists of small molecule basic structure unit, while SDI is largely made from macromolecular structure unit. Based on bond-level parameters of the molecular model, the research found through the autoclave experiment that vitrinite liquefaction process goes under thermodynamics control and inertinite liquefaction process under dynamics control. The research developed an efficient directional direct coal liquefaction technology based on the maceral characteristics of Shenhua coal, which can effectively improve oil yield and lower gas yield.
\end{abstract}

Keywords Liquefaction $\cdot$ Maceral $\cdot$ Molecular model $\cdot$ Shenhua coal $\cdot$ Directional direct coal liquefaction

\section{Introduction}

Generally, direct coal liquefaction process chooses coal as the single feedstock and aims to produce distillable liquids. This process lends itself to coal with low level of inertinite if maximum liquids production is a prerequisite for the selection of process route and appropriate reaction conditions in a reaction system. China Coal Research Institute conducted a study on properties of Chinese coal for direct liquefaction (Shu and Xu 1997) and selected 15 types of coals suitable for direct liquefaction, with inertinite content of the top 10 all less than $7 \%$. However, Shenhua coal maceral has higher inertinite content level, with some even more than $60 \%$, than that of any other coals in China or

G. Shu $(\bowtie) \cdot$ Y. Zhang

Shenhua Group Co., Ltd., Beijing 100011, China

e-mail: shugeping@csclc.com even in the world. Therefore, it is necessary to study the maceral structures of Shenhua coal and consequent differences of their liquefaction performance and then develop an efficient directional direct liquefaction technology based on the characteristics of Shenhua coal maceral.

\section{Experimental}

\subsection{Sample preparation}

Shenhua coal samples (SDR) were collected from Shangwan coal mine, Shendong, Inner Mongolia. The raw coal was prepared by hand and a drifting process to obtain vitrinite concentrates (SDV) and inertinite concentrates (SDI). Industrial analysis and elemental analysis of Shenhua coal, vitrinite concentrates and inertinite concentrates are shown in Table 1, as well as petrographical analysis in Table 2. 
Table 1 Proximate and ultimate analysis of coal samples

\begin{tabular}{|c|c|c|c|c|c|c|c|c|}
\hline \multirow[t]{2}{*}{ Sample } & \multicolumn{4}{|c|}{ Proximate analysis (w \%) } & \multicolumn{4}{|c|}{ Ultimate analysis $\left(W_{\mathrm{daf}} \%\right)$} \\
\hline & $M_{\mathrm{ad}}$ & $A_{\mathrm{d}}$ & $V_{\mathrm{daf}}$ & $C$ & $\mathrm{H}$ & $\mathrm{N}$ & S & $\mathrm{O}^{*}$ \\
\hline SDR & 8.45 & 17.03 & 38.19 & 79.29 & 4.30 & 0.86 & 0.47 & 15.08 \\
\hline SDI & 10.96 & 5.27 & 30.59 & 82.12 & 3.79 & 0.86 & 0.40 & 12.83 \\
\hline SDV & 10.60 & 2.27 & 40.47 & 80.55 & 4.72 & 1.06 & 0.41 & 13.26 \\
\hline
\end{tabular}

* By differences, SDR Shendong coal, SDV vitrinite concentrate obtained from Shendong coal, SDI inertinite concentrate obtained from Shendong coal

Table 2 Petrographical analysis $\%$

\begin{tabular}{lllll}
\hline Sample & Vitrinite & Inertinite & Exinite & $R_{\max }$ \\
\hline SDV & 82.2 & 16.4 & 0.7 & \\
SDR & 42.5 & 52.3 & 0.8 & 0.519 \\
SDI & 17.8 & 80.1 & 0.5 & \\
\hline
\end{tabular}

\section{$2.2{ }^{13} \mathrm{C}-\mathrm{NMR}$ analysis characterization}

The research adopted an NMR AVANCE400 superconducting spectrometer produced by Bruker company, with a solid double resonance probe, and a $4 \mathrm{~mm} \mathrm{ZrO}_{2}$ rotor; magic-angle speed was set at $8,000 \mathrm{~Hz}$, resonance frequency $100.13 \mathrm{MHz}$, the sampling time $0.05 \mathrm{~s}$, pulse wide $4 \mu \mathrm{s}$, cyclic delay time $5 \mathrm{~s}$, and 7,000 scan times. The cross polarization $(\mathrm{CP})$ technology was applied as well.

\subsection{FTIR analysis characterization}

Instrument type: US Nicolet 6700 FT-IR; test conditions: wavelength range: $4,000-400 \mathrm{~cm}^{-1}$, accuracy: wave number $\leq 0.1 / \mathrm{cm}$; transmittance $\leq 0.1$, resolution: $4 \mathrm{~cm}^{-1}$, number of scans: 32 times.

\subsection{X-ray diffraction XRD}

Instrument type: D/MAX $2550 \mathrm{VB} / \mathrm{PC}$, manufacturer: Japan RIGAKU. Test method: wavelength: 1.54056 angstrom; copper target: $40 \mathrm{kV}, 100 \mathrm{~mA}$; scanning speed: 12 degrees/min, step: 0.02 degree.

\subsection{XPS analysis characterization}

XPS measurement is conducted with ESCALAB250 X-ray photoelectron spectroscopy. Use AlKa anode, and the power is $200 \mathrm{~W}$. The full scan penetration power is $150 \mathrm{eV}$, step length $0.5 \mathrm{eV}$; narrow scan penetration power $60 \mathrm{eV}$, step $0.05 \mathrm{eV}$. Basic vacuum is $10^{-7} \mathrm{~Pa}$. Take $\mathrm{C} 1 \mathrm{~s}(284.6 \mathrm{eV})$ as the calibration standard. The ordinate in the XPS spectra represents electronic counting, while the abscissa shows the electron binding energy (Binding Energy, B.E.).
2.6 Experiment of coal liquefaction reaction in autoclave

The coal liquefaction experiment used $0.5 \mathrm{~L}$ stirred autoclave, and the standard experimental conditions are as follows: coal input is $28 \mathrm{~g}$ (dry coal), initial hydrogen pressure is $10.0 \mathrm{MPa}$, the mass ratio of solvent to the coal is 1.5:1, the catalyst is $\mathrm{Fe}_{2} \mathrm{O}_{3}$, the additive amount of $\mathrm{Fe}$ is $3 \%$ of the mass of dry coal, sulfur is the co-catalyst, $n(\mathrm{~S}) /$ $n(\mathrm{Fe})=2$. Heating rate is $8{ }^{\circ} \mathrm{C} / \mathrm{min}$ till the set reaction temperature is reached. After the reaction, the temperature in the autoclave drops to $200{ }^{\circ} \mathrm{C}$ within $20 \mathrm{~min}$. Products out of the autoclave include two parts: gaseous phase products, the component of which is analyzed with gas chromatography, and liquid-solid mixture which gets Soxhlet extraction separation successively with n-hexane and then tetrahydrofuran, finding that n-hexane soluble substance is oil, $\mathrm{n}$-hexane insoluble and THF-soluble substances consist of pre-asphaltene and asphaltene (for short, PPA), THF-insoluble substances contains unreacted coal and ash. Analytical extraction procedures can be seen in literature (Shu et al. 2003).

2.7 Bench-scale unit for continuous direct coal liquefaction experiment

The continuous direct coal liquefaction experiment used a small continuous bench-sacle unit (BSU) with daily handling capacity of $120 \mathrm{~kg}$ of dry coal. Ordinary process unit has a reaction system of two bubbling bed reactors in series, while the reaction system of Shenhua unit has two reactors in series equipped with a circulating pump at the bottom and a gas-liquid separator on the top (Shu 2009).

\section{Results and discussions}

\subsection{Macromolecular structure model of SDV and SDI}

${ }^{13} \mathrm{C}-\mathrm{CP} / \mathrm{MAS}$ NMR analytical characterization, X-ray diffraction, FTIR analytical characterization, X-ray diffraction $\mathrm{XRD}$, and XPS analytical characterization were applied to the sample.

${ }^{13} \mathrm{C}$-CP/MAS NMR peak-fitting spectra of Shendong Shangwan SDV and SDI are illustrated respectively in Figs. 1 and 2, with the structure parameters shown in Table 3.

It can be observed from Figs. 1 and $2,{ }^{13} \mathrm{C}$ spectra of Shendong coal obviously has two peaks, one chemical shift located at aliphatic carbon of 0-60 ppm and the other at aromatic area of 90-165 ppm. However, these two samples at the aromatic area are obviously larger than those at the 


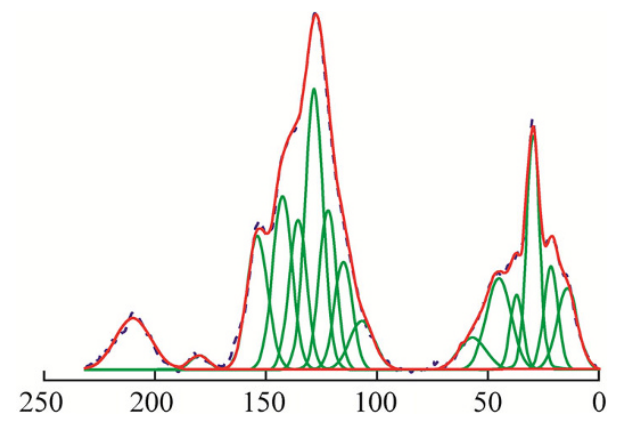

Fig. $1{ }^{13} \mathrm{C}-\mathrm{CP} / \mathrm{MAS}$ NMR spectra of Shenhua coal vitrinite

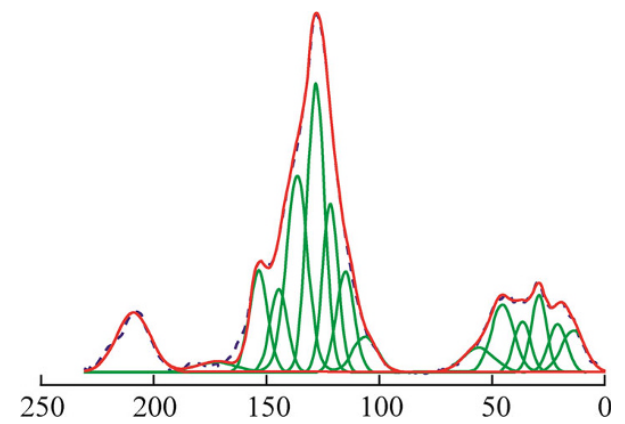

Fig. $2{ }^{13} \mathrm{C}-\mathrm{CP} / \mathrm{MAS}$ NMR spectra of Shenhua coal inertinite

aliphatic area, and the aliphatic area of inertinite group is obviously smaller than that of vitrinite group.

Aromaticity $\left(f_{\mathrm{a}}^{\prime}\right)$ is an important parameter of coal structure. As can be seen from Table 5, aromaticity of inertinite is obviously higher than that of vitrinite. There is a big difference between inertinite at $67.47 \%$ and vitrinit at $61.47 \%$. The comparison concludes that the biggest difference of aromatic carbon is caused by $f_{\mathrm{a}}^{c}$ (carbonyl), $f_{\mathrm{a}}^{\mathrm{S}}$ (alkylated aromatic) and $f_{\mathrm{a}}^{\mathrm{B}}$ (aromatic bridgehead). The vitrinite has more alkylated aromatic, while the inertinite has more aromatic bridgehead.

The ratio of aromatic bridgehead carbons to total ring carbons serves as an important parameter to research the macromolecular structure of coal, which can be used to calculate the size of aromatic clusters in coal structures. The types and number of aromatic structure units in the molecular structure of coal can be basically determined on the basis of this parameter. The hydrogen aromaticity is used to represent the concentration of aromatic hydrogen in coal structure, with its formula of calculation as below: $H_{\mathrm{a}}=(\mathrm{C} / \mathrm{H})_{\text {atom }} \times f_{\mathrm{a}}^{\mathrm{H}}$. The values of $X_{\mathrm{b}}$ and $H_{\mathrm{a}}$ of these two samples are shown in Table 4.

As can be seen from the $X_{\mathrm{b}}$ values in Table 4 , the ratios of aromatic bridgehead carbons to total ring carbons for SDV and SDI are very different. This indicates that these two coal samples have a big difference in macromolecular structure. The ratio of inertinite group is 0.307 , much more

Table 4 Coal-related structure parameters

\begin{tabular}{lll}
\hline Sample & $X_{\mathrm{b}}$ & $H_{\mathrm{a}}$ \\
\hline SDV & 0.154 & 2.29 \\
SDI & 0.307 & 2.67 \\
\hline
\end{tabular}

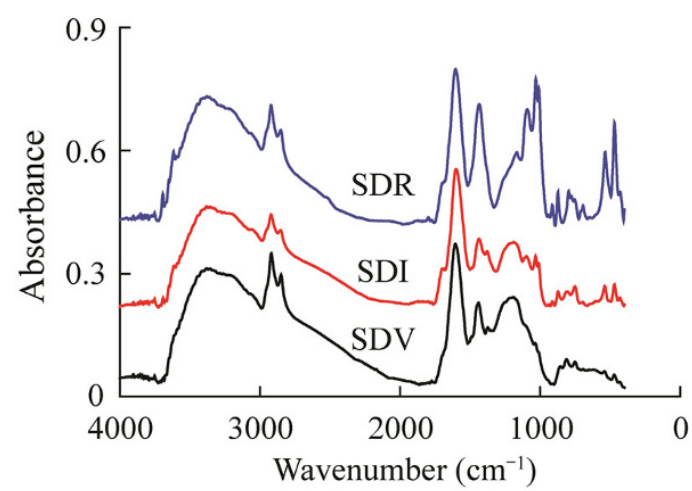

(a) $400-4000 \mathrm{~cm}^{-1}$ spectra

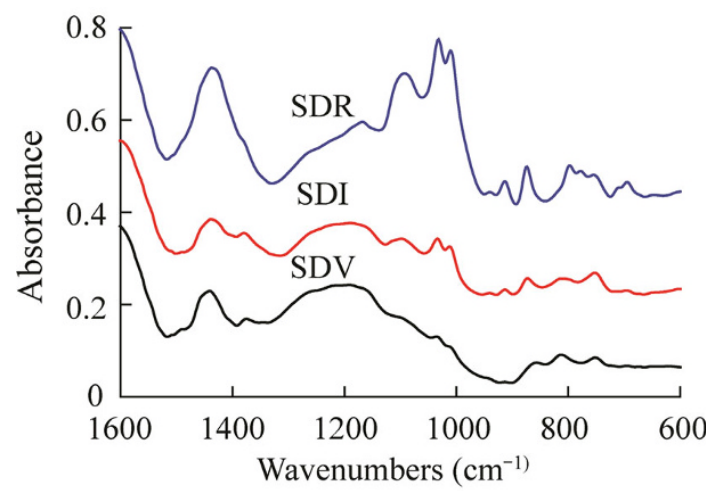

(b) $600-1600 \mathrm{~cm}^{-1}$ spectra

Fig. 3 FTIR spectra of SDV and SD

Table 3 Structure parameters of samples \%

\begin{tabular}{|c|c|c|c|c|c|c|c|c|c|c|c|c|}
\hline Sample & $f_{\mathrm{a}}$ & $f_{\mathrm{a}}^{c}$ & $f_{\mathrm{a}}^{\prime}$ & $f_{\mathrm{a}}^{\mathrm{N}}$ & $f_{\mathrm{a}}^{\mathrm{H}}$ & $f_{\mathrm{a}}^{\mathrm{P}}$ & $f_{\mathrm{a}}^{\mathrm{s}}$ & $f_{\mathrm{a}}^{\mathrm{B}}$ & $f_{\text {al }}$ & $f_{\mathrm{al}}^{*}$ & $f_{\mathrm{al}}^{\mathrm{H}}$ & $f_{\mathrm{al}}^{\mathrm{O}}$ \\
\hline SDV & 67.96 & 6.49 & 61.47 & 27.39 & 34.09 & 8.77 & 10.43 & 8.18 & 32.03 & 16.76 & 12.60 & 2.68 \\
\hline SDI & 76.71 & 9.24 & 67.47 & 28.5 & 38.97 & 7.15 & 5.49 & 15.87 & 23.29 & 7.05 & 13.38 & 2.86 \\
\hline
\end{tabular}

$f_{\mathrm{a}}$ Total aromatic carbon, $f_{\mathrm{al}}$ total aliphatic carbon, $f_{\mathrm{a}}^{\mathrm{c}}$ carbonyl $\delta$ (chemical shift) $>165 \times 10^{-6}, \dot{f_{\mathrm{a}}}$ in an aromatic ring, $f_{\mathrm{a}}^{\mathrm{H}}$ protonated and aromatic, $f_{\mathrm{a}}^{\mathrm{N}}$ onprotonated and aromatic, $f_{\mathrm{a}}^{\mathrm{P}}$ phenolic or phenolic ether, $f_{\mathrm{a}}^{\mathrm{s}}$ alkylated aromatic, $f_{\mathrm{a}}^{\mathrm{B}}$ aromatic bridgehead, $f_{\mathrm{al}}^{*} \mathrm{CH}_{3}$ or nonprotonated, $f_{\mathrm{al}}^{\mathrm{H}}(\mathrm{CH}$ or $\mathrm{CH}_{2}, f_{\mathrm{al}}^{\mathrm{O}}$ bonded to oxygen 
than vitrinite group (0.154). With respect to $H_{\mathrm{a}}$, the inertinite group is higher, indicating that its coal structure has more aromatic ring structures. Such result remains consistent with the result of $X_{b}$.

The Fig. 3 illustrates the FTIR spectroscopic analysis spectra of SDV concentrates and SDI concentrates.

The ratio of aliphatic hydrogen $\left(H_{\mathrm{al}}\right)$ and aromatic hydrogen $\left(H_{\mathrm{ar}}\right)$ in the coal serves as an important parameter to research the coal structure, and in general the ratio of $2,800-3,000 \mathrm{~cm}^{-1}$ aliphatic-CH stretching vibration absorption area to $700-900 \mathrm{~cm}^{-1}$ aromatic- $\mathrm{CH}$ bending vibration absorption area represents the proportion of aliphatic hydrogen to aromatic hydrogen. Peak-fitting information was obtained through peak-fitting analysis of the

Table 5 Relevant parameters of three samples of SDR, SDV and SDI

\begin{tabular}{llll}
\hline Sample & Calculation & SDV & SDI \\
\hline$H_{\mathrm{al}} / H_{\mathrm{ar}}$ & $A_{2,800-3,000} / A_{700-900}$ & 2.18 & 1.36 \\
Aliphatics/aromatics & $A_{2,800-3,000} / A_{1,600}$ & 0.36 & 0.23 \\
$v\left(\mathrm{CH}_{2}\right) / v\left(\mathrm{CH}_{3}\right)$ & $A_{2,926+2,854} / A_{2,956+2,875}$ & 3.83 & 3.62 \\
\hline
\end{tabular}

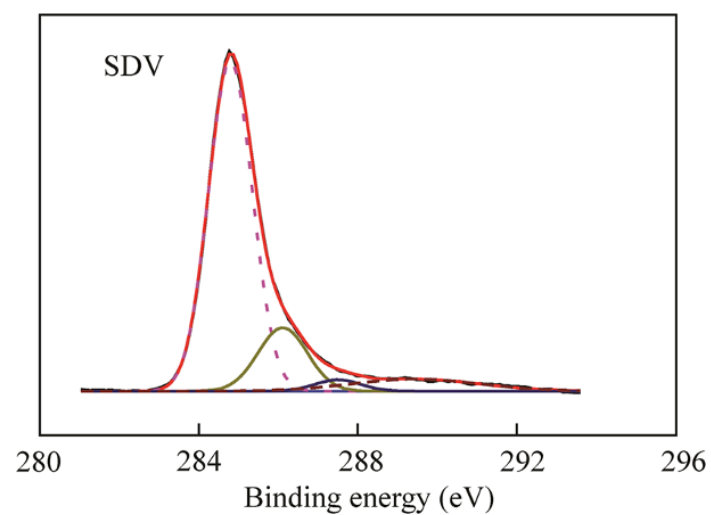

Fig. 4 C1s X-ray photoelectron spectroscopy of SDV

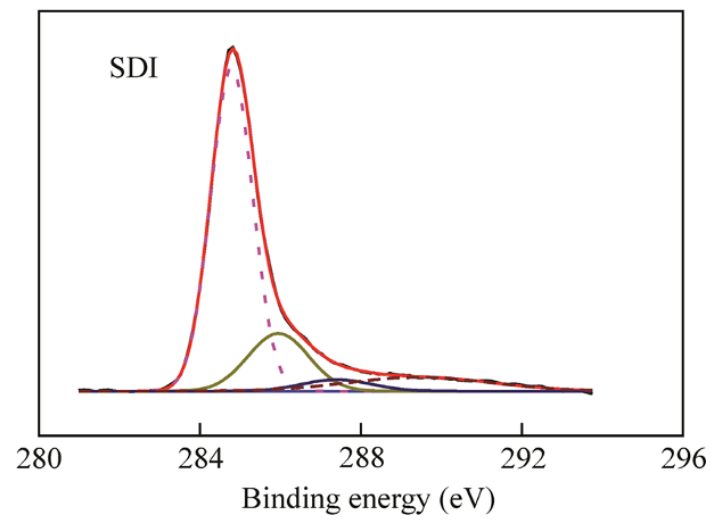

Fig. 5 C1s X-ray photoelectron spectroscopy of SDI infrared spectra of two coal samples, and the relevant structure parameter is calculated with the information. See it in Table 5. As can be seen from Table 5, the value of $H_{\mathrm{al}} / H_{\mathrm{ar}}$ of SDV is 2.18 , much higher than that of SDI (1.36), which indicates the structure has more aliphatic structure; it can be seen through $A_{2,800-3,000} / A_{1,600}$ that SDI is much smaller than SDV, indicating there are more aromatic frame in its structures; the ratio of $v\left(\mathrm{CH}_{2}\right) / v\left(\mathrm{CH}_{3}\right)$ leads to the conclusion that vitrinite and inertinite have more stretching vibration $\mathrm{CH}_{2}$. These all provide information for establishing macromolecular structure of coal.

Table 6 XPS C1s analysis of coal sample

\begin{tabular}{lllr}
\hline B.E./eV & Carbon form & \multicolumn{2}{l}{ Content $\left(W_{\text {mol }} \%\right)$} \\
\cline { 3 - 4 } & & SDV & SDI \\
\hline 284.8 & C-C,C-H & 73.90 & 68.50 \\
286.2 & C-O & 15.85 & 17.57 \\
287.5 & C=O & 2.58 & 3.99 \\
289.6 & COO- & 7.67 & 9.94 \\
\hline
\end{tabular}

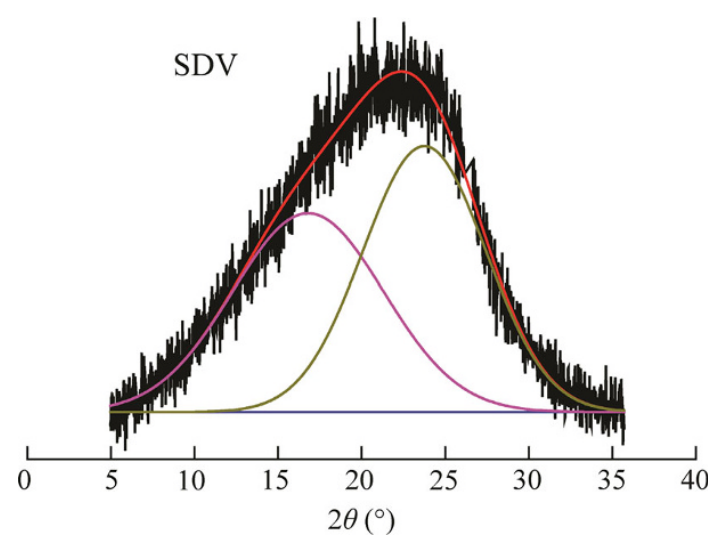

Fig. 6 5-40 XRD and peak-fitting graph of SDV sample

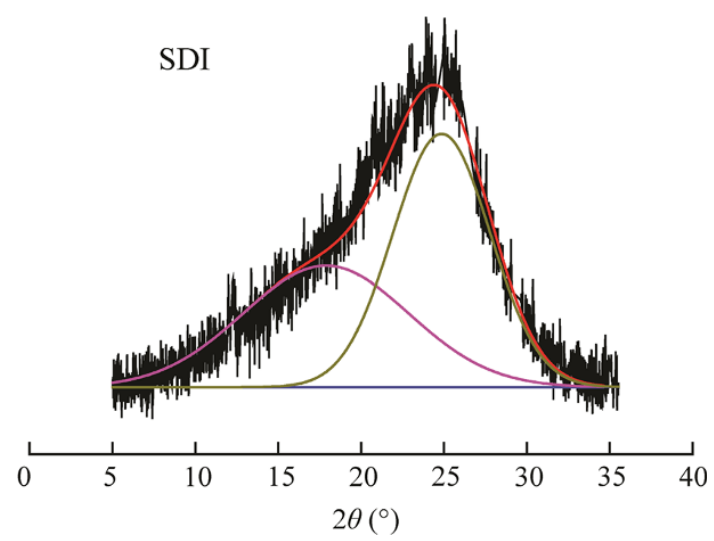

Fig. 7 5-40 XRD and peak-fitting graph of SDI sample 
Table 7 XRD structure parameters of SDV and SDI

\begin{tabular}{|c|c|c|c|c|c|c|c|c|c|c|}
\hline Samples & $2 \theta_{002}\left({ }^{\circ}\right)$ & $\beta_{002}$ & $2 \theta_{\gamma}\left({ }^{\circ}\right)$ & $\theta_{100}\left(^{\circ}\right)$ & $d_{002}(\AA)$ & $d_{\gamma}\left({ }^{\circ}\right)$ & $L_{\mathrm{c}}\left({ }^{\circ}\right)$ & $L_{\mathrm{a}}\left({ }^{\circ}\right)$ & $N_{\mathrm{c}}$ & $f_{\mathrm{a}}$ \\
\hline SDV & 23.77 & 8.645 & $16.82,10.64$ & $42.65,10.77$ & 3.74 & 5.27 & 9.81 & 16.19 & 2.62 & 0.52 \\
\hline SDI-1 & 24.86 & 6.924 & $17.88,11.80$ & $43.72,9.38$ & 3.58 & 4.96 & 12.27 & 18.66 & 3.43 & 0.55 \\
\hline
\end{tabular}

$d_{002}\left({ }^{\circ}\right)$ Inter aromatic layer distance, $\mathrm{nm} ; L_{\mathrm{c}}$ diameter of the aromatic clusters perpendicular to the plane of the sheet, nm; $L_{\mathrm{a}}$ diameter of aromatic sheet carbons of side chains from diamond's curve(10) band, nm; $N_{\mathrm{c}}$ average number of aromatic sheets associated in a stacked cluster; $f_{\mathrm{a}}=C_{\mathrm{A}} / C_{\text {total }}=A_{002} /\left(A_{002}+A \gamma\right)$

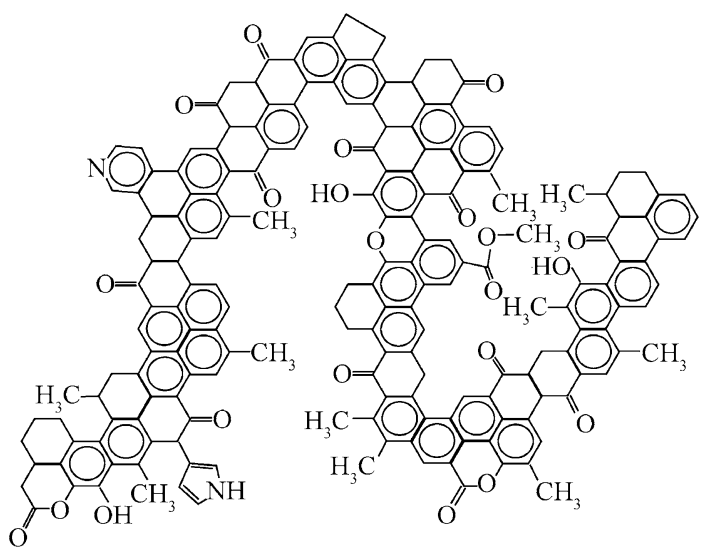

Fig. 8 Modified structural model of inertinite

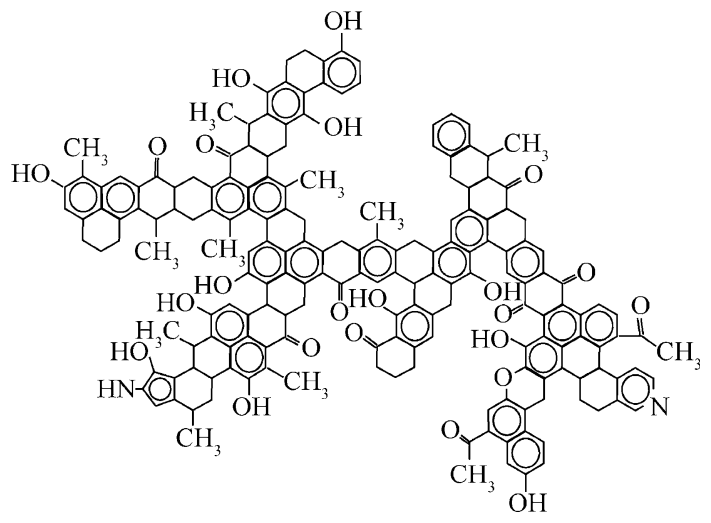

Fig. 9 Modified structural model of vitrinite

The XPS C1s spectra and peak-fitting graphs of SDV and SDI samples are illustrated respectively in Figs. 4 and 5 . As can be seen from the figures, carbon has four forms in the coal surface structure. The peak $284.6 \mathrm{eV}$ is attributable to aromatic unit and alkyl-substituted aromatic carbon $(\mathrm{C}-\mathrm{C}, \mathrm{C}-\mathrm{H})$; the peak $286.3 \mathrm{eV}$ is attributable to phenolic carbon or ether carbon $(\mathrm{C}-\mathrm{O})$; the peak $287.5 \mathrm{eV}$ is attributable to carbonyl $(\mathrm{C}=\mathrm{O})$ and the peak $289.0 \mathrm{eV}$ belongs to carboxyl (COO-). Table 6 shows the XPS C1s results and distribution of samples.

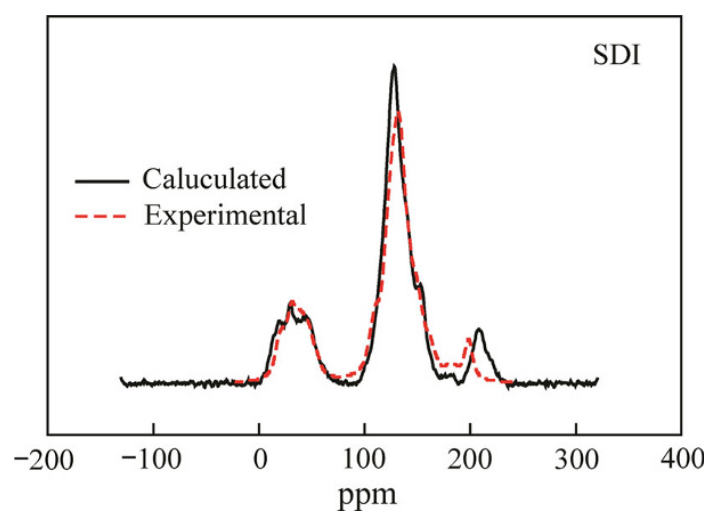

Fig. 10 The comparison between calculated values and experimental values of inertinite ${ }^{13} \mathrm{C}$-NMR

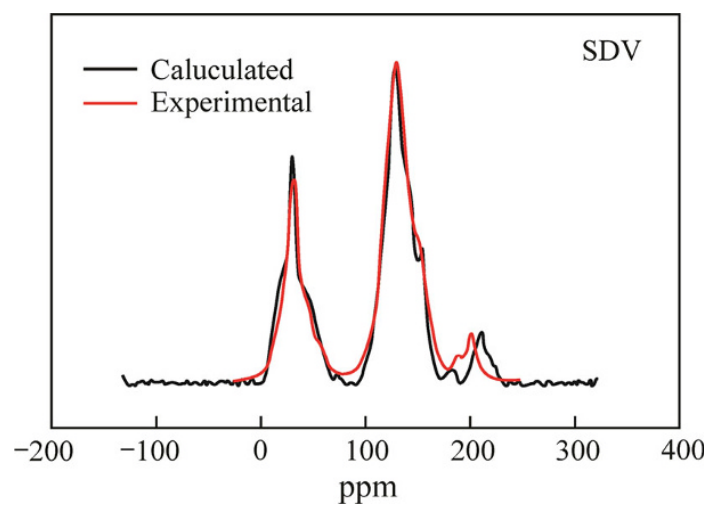

Fig. 11 The comparison between calculated values and experimental values of vitrinite ${ }^{13} \mathrm{C}-\mathrm{NMR}$

As can be seen from Table 6, the surface structure of SDI has less content of $\mathrm{C}-\mathrm{C}, \mathrm{C}-\mathrm{H}$, indicating less alkyl side chains. A part of alkyl side chains are transformed into phenolic hydroxyl group and ether linkage under the effect of fusainization, which leads to the relatively higher mass fraction of $\mathrm{C}-\mathrm{O}$ in SDI.

The 5-40 XDR peak-fitting graphs for SDV and SDI samples are illustrated respectively in Figs. 6 and 7. XDR structure parameter is shown in Table 7.

Using the ACD/CNMR predictor combined with data in Table 1, the research established SDV and SDI structure models respectively, as illustrated in Figs. 8 and 9. A ${ }^{13} \mathrm{C}$ 
Table 8 SDV bond order distribution

\begin{tabular}{|c|c|c|c|c|c|}
\hline $\begin{array}{l}\text { Bond } \\
\text { name }\end{array}$ & $\begin{array}{l}\text { Bond } \\
\text { order }\end{array}$ & $\begin{array}{l}\text { Bond } \\
\text { name }\end{array}$ & $\begin{array}{l}\text { Bond } \\
\text { order }\end{array}$ & $\begin{array}{l}\text { Bond } \\
\text { name }\end{array}$ & $\begin{array}{l}\text { Bond } \\
\text { order }\end{array}$ \\
\hline 192-C209 & 0.860 & C137-C136 & 0.991 & C74-C82 & 1.2 \\
\hline 46-O44 & .885 & C136-C133 & 0.991 & C97-C96 & 1.2 \\
\hline 107-C110 & 0.929 & C28-C31 & 0.991 & C15-C14 & 1.2 \\
\hline $205-\mathrm{C} 180$ & 0.933 & C209-C57 & 0.992 & C149-C147 & 1.27 \\
\hline 47-C45 & 938 & C58-C57 & 0.992 & C146-C140 & 1.27 \\
\hline 106-C187 & 0.938 & C67-C66 & 0.994 & C33-C32 & 1.28 \\
\hline $28-\mathrm{C} 26$ & .940 & C135-C134 & 0.995 & C62-C61 & 1.28 \\
\hline $114-\mathrm{C} 110$ & 0.943 & $\mathrm{C} 211-\mathrm{C} 172$ & 0.995 & C119-C & 1.28 \\
\hline $123-\mathrm{C} 120$ & 0.944 & C168-C167 & 0.995 & C144-C143 & 1.28 \\
\hline C57-C54 & 0.944 & $\mathrm{C} 43-\mathrm{C} 14$ & 0.996 & C39-C37 & 1.29 \\
\hline C210-C108 & 946 & C162-C157 & 0.996 & C64-C62 & 1.29 \\
\hline C213-C186 & 0.947 & C102-C100 & 0.997 & C180-C17 & 1.29 \\
\hline C115-C114 & 0.948 & C20-O190 & 0.997 & C160-C159 & 1.29 \\
\hline C59-C55 & 0.948 & C36-C35 & 1.000 & C175-C111 & 1.29 \\
\hline $\mathrm{C} 122-\mathrm{C} 121$ & 0.949 & $\mathrm{C} 120-\mathrm{C} 25$ & 1.000 & C60-C63 & 1.29 \\
\hline C200-C199 & 0.950 & C9-C191 & 1.000 & C131-C130 & 1.30 \\
\hline C102-C195 & 0.950 & $\mathrm{O} 44-\mathrm{C} 15$ & 1.001 & C88-C85 & 1.30 \\
\hline C167-C164 & & C216-C106 & 1.001 & & 1.30 \\
\hline C27-C26 & & O152-C149 & & & 1.30 \\
\hline & & & & & 1.30 \\
\hline & & & & & 1.30 \\
\hline & & & & & 1.31 \\
\hline & & & & & 1.31 \\
\hline & & & & & 1.31 \\
\hline & & & & & 1.51 \\
\hline 00-C71 & & & & & 1.31 \\
\hline $3-\mathrm{C} 162$ & & & & & 1.31 \\
\hline C215-C210 & & & & & 1.317 \\
\hline & & & & & 1.31 \\
\hline & & & & & 1.32 \\
\hline-0152 & & & & & 1.32 \\
\hline C92-C91 & & & & C182-C181 & 1.32 \\
\hline C84-C73 & & & & & 1.32 \\
\hline C198-C102 & & O183-C24 & & C169 & 1.330 \\
\hline C91-C90 & & & & 2-C111 & 1.332 \\
\hline C215-C177 & & 6-C148 & & & 1.33 \\
\hline C165-C164 & & & & & 1.33 \\
\hline C217-C215 & & & & $133-\mathrm{C} 131$ & 1.33 \\
\hline C73-C74 & & & & & 1.33 \\
\hline C199-C210 & & & 1.063 & & 1.33 \\
\hline C111-C109 & & & 1.072 & & 1.33 \\
\hline C204-C198 & & C79-C119 & 1.077 & C171-C169 & 1.33 \\
\hline C11-C54 & & & & & 1.34 \\
\hline $\mathrm{C} 122-\mathrm{C} 120$ & & C129-N128 & 1.117 & C133-C132 & 1.34 \\
\hline C126-C124 & 0.971 & C140-C139 & 1.149 & C176-C175 & 1.34 \\
\hline C200-C193 & & C135-C138 & 1.160 & $\mathrm{C} 23-\mathrm{C} 22$ & 1.35 \\
\hline C48-C46 & & C141-C137 & 1.160 & C178-C177 & 1.35 \\
\hline C108-C107 & 0.974 & $\mathrm{~N} 128-\mathrm{C} 127$ & 1.182 & $\mathrm{C} 40-\mathrm{C} 38$ & 1.357 \\
\hline
\end{tabular}

Table 8 continued

\begin{tabular}{|c|c|c|c|c|c|}
\hline $\begin{array}{l}\text { Bond } \\
\text { name }\end{array}$ & $\begin{array}{l}\text { Bond } \\
\text { order }\end{array}$ & $\begin{array}{l}\text { Bond } \\
\text { name }\end{array}$ & $\begin{array}{l}\text { Bond } \\
\text { order }\end{array}$ & $\begin{array}{l}\text { Bond } \\
\text { name }\end{array}$ & $\begin{array}{l}\text { Bond } \\
\text { order }\end{array}$ \\
\hline C77-C107 & 0.975 & $\mathrm{C} 7-\mathrm{C} 5$ & 1.188 & C147-C146 & 1.358 \\
\hline $\mathrm{C} 45-\mathrm{C} 43$ & 0.975 & C157-C155 & 1.192 & C25-C24 & 1.359 \\
\hline C198-C197 & 0.975 & C19-C22 & 1.193 & $\mathrm{C} 11-\mathrm{C} 10$ & 1.369 \\
\hline C195-C194 & 0.975 & $\mathrm{C} 6-\mathrm{C} 2$ & 1.194 & C29-C33 & 1.373 \\
\hline C72-C71 & 0.975 & $\mathrm{C} 16-\mathrm{C} 20$ & 1.197 & C9-C6 & 1.382 \\
\hline C65-C66 & 0.976 & $\mathrm{C} 80-\mathrm{C} 79$ & 1.198 & $\mathrm{C} 5-\mathrm{C} 4$ & 1.384 \\
\hline C186-C94 & 0.977 & $\mathrm{C} 13-\mathrm{C} 12$ & 1.199 & C79-C78 & 1.389 \\
\hline $\mathrm{C} 125-\mathrm{C} 122$ & 0.977 & C30-C31 & 1.202 & $\mathrm{C} 20-\mathrm{C} 18$ & 1.389 \\
\hline C212-C211 & 0.978 & C97-C95 & 1.204 & C145-C144 & 1.389 \\
\hline C193-C53 & 0.979 & $\mathrm{C} 100-\mathrm{C} 97$ & 1.207 & $\mathrm{C} 17-\mathrm{C} 16$ & 1.390 \\
\hline C33-C36 & 0.979 & C50-C49 & 1.209 & C178-C176 & 1.393 \\
\hline C165-C145 & 0.980 & C155-C154 & 1.212 & C96-C50 & 1.394 \\
\hline C196-C194 & 0.980 & C98-C95 & 1.213 & C173-C170 & 1.395 \\
\hline C90-C87 & 0.981 & $\mathrm{C} 17-\mathrm{C} 21$ & 1.215 & C34-C39 & 1.397 \\
\hline C214-C144 & 0.981 & $\mathrm{C} 126-\mathrm{C} 125$ & 1.216 & C153-C151 & 1.401 \\
\hline $\mathrm{C} 124-\mathrm{C} 123$ & 0.981 & $\mathrm{C} 7-\mathrm{C} 12$ & 1.217 & C74-C72 & 1.405 \\
\hline C1-C3 & 0.981 & $\mathrm{C} 76-\mathrm{C} 75$ & 1.219 & $\mathrm{C} 101-\mathrm{C} 100$ & 1.409 \\
\hline C108-C112 & 0.983 & $\mathrm{C} 21-\mathrm{C} 19$ & 1.219 & C31-C41 & 1.411 \\
\hline C113-C109 & 0.983 & C154-C151 & 1.219 & C75-C77 & 1.412 \\
\hline C71-C37 & 0.984 & $\mathrm{C} 25-\mathrm{C} 21$ & 1.222 & N174-C172 & 1.413 \\
\hline C89-C88 & 0.984 & C19-C18 & 1.227 & C86-C83 & 1.416 \\
\hline C204-C103 & 0.984 & $\mathrm{C} 30-\mathrm{C} 2$ & 1.230 & C94-C49 & 1.420 \\
\hline $\mathrm{C} 121-\mathrm{C} 17$ & 0.984 & C95-C94 & 1.231 & N174-C173 & 1.421 \\
\hline C115-C117 & 0.984 & C141-C140 & 1.231 & $\mathrm{C} 1-\mathrm{C} 32$ & 1.430 \\
\hline C53-C39 & 0.984 & C76-C80 & 1.232 & $\mathrm{C} 127-\mathrm{C} 125$ & 1.436 \\
\hline C169-C165 & 0.984 & C9-C41 & 1.234 & C82-C81 & 1.451 \\
\hline C110-C109 & 0.985 & C4-C10 & 1.234 & C161-C160 & 1.451 \\
\hline C103-C101 & 0.985 & $\mathrm{C} 81-\mathrm{C} 80$ & 1.235 & C157-C156 & 1.455 \\
\hline $\mathrm{C} 151-\mathrm{C} 150$ & 0.986 & C156-C153 & 1.237 & C99-C98 & 1.461 \\
\hline C199-C75 & 0.986 & $\mathrm{C} 24-\mathrm{C} 23$ & 1.237 & C142-C143 & 1.467 \\
\hline C218-C81 & 0.986 & $\mathrm{C} 12-\mathrm{C} 11$ & 1.238 & C159-C158 & 1.471 \\
\hline C197-C196 & 0.987 & $\mathrm{C} 72-\mathrm{C} 76$ & 1.238 & $\mathrm{C} 129-\mathrm{C} 126$ & 1.475 \\
\hline C42-C29 & 0.987 & $\mathrm{C} 30-\mathrm{C} 29$ & 1.240 & C137-C135 & 1.501 \\
\hline $\mathrm{C} 42-\mathrm{C} 26$ & 0.987 & $\mathrm{C} 1-\mathrm{C} 2$ & 1.246 & O70-C56 & 1.810 \\
\hline C49-C48 & 0.988 & C78-C77 & 1.250 & O93-C27 & 1.843 \\
\hline C146-C164 & 0.988 & C139-C138 & 1.253 & O52-C36 & 1.859 \\
\hline C18-C28 & 0.988 & C101-C99 & 1.254 & O51-C47 & 1.877 \\
\hline C61-C65 & 0.989 & C148-C141 & 1.254 & O208-C92 & 1.877 \\
\hline C118-C117 & 0.989 & C154-C158 & 1.255 & O116-C114 & 1.903 \\
\hline C150-C147 & 0.989 & C139-C145 & 1.255 & O207-C187 & 1.911 \\
\hline C73-C38 & 0.990 & C161-C155 & 1.265 & C8-C7 & 1.269 \\
\hline C134-C131 & 0.990 & C138-C142 & 1.268 & $\mathrm{C} 171-\mathrm{C} 214$ & 0.990 \\
\hline
\end{tabular}

NMR calculation of the structure models was carried out, the result of which fitted well with the experimental spectrum of the sample, as illustrated in Figs. 10 and 11. 
3.2 Study on reactivity of vitrinite concentrates and inertinite concentrates

By using Dmol3 module of the Materials Studio software, the research did calculations of the structure of the SDV molecular model which had been optimized through molecular dynamics and molecular mechanics calculations, and obtained its bond order, bond length, and electronic layouts charge number. Bond order distribution of SDV is shown in Table 8.

The bond order parameters of molecular structure may determine the active sites where chemical bonds break down, thereby to infer the relations between molecular structure and its pyrolysis. According to the data in Table 8 and in combination of analyzing calculated bond length and electronic layouts number, SDI bond with order parameters smaller than one breaks down under a certain temperature. It is concluded that in SDV molecular structure, weak bridge bonds, ether bond, aliphatic side chain, hydrogenated aromatic ring, carbonyl functional groups and the distorted parts of aromatic layer are more likely to break down, producing $\mathrm{CO}, \mathrm{CO}_{2}, \mathrm{CH}_{4}$, monocyclic aromatic hydrocarbons and aliphatic hydrocarbons with two carbon atoms, and first-level fragments with larger molecular weights. SDV releases by pyrolysis a large number of small molecular hydrocarbons, and the macromolecular structure of coal is basically destroyed. See SDV active sites and pyrolysis in Fig. 12.

Using Dmol3 module of the Materials Studio software, the research made calculations of the structure of the SDI molecular model, which has been optimized through molecular dynamics and molecular mechanics calculations, and obtained its bond order, bond length, and electronic layouts charge number. Bond order distribution of SDI can be seen in Table 9.
According to the data in Table 9, in combination of analyzing calculated bond length and electronic layouts number, SDI with bond order parameters smaller than one breaks down under a certain temperature. SDI bond breaking occurs in the location of hydrogenated aromatic ring and carbonyl functional group, producing $\mathrm{CH}_{4}, \mathrm{CO}_{2}$, bicyclic aromatics and first-level fragments with larger molecular weights. SDV and SDI vary greatly in this phase of pyrolysis. Bond breaking points of SDV are far more than that of SDI; SDV releases through pyrolysis large amounts of small molecule hydrocarbons, leading to coal macromolecular structure basically being destroyed, while SDI releases less small molecules and obtains through pyrolysis first-level fragments with larger molecular weights. See SDI active sites and the schematic representation of pyrolysis in Fig. 13.

The analysis of maceral bond order parameters demonstrates that liquefaction mechanisms for SDV and SDI are different. For SDV, it produces pyrolysis products with small molecular weights and has a high conversion rate. To improve the yield rate of its liquefaction is to quickly stabilize active free radicals and prevent the subsequent secondary pyrolysis. The whole process is subject to thermodynamics control.

For SDI, it produces pyrolysis products with large molecular weights. To improve the yield rate of its liquefaction is to increase hydrocracking activity and severity of its macromolecule products. The whole process is subject to dynamics control.

\subsection{Autoclave experiment of SDV and SDI}

To prove the difference of liquefaction reaction mechanisms between SDI and SDV, hydrogenation liquefaction experiments in an autoclave were conducted respectively.

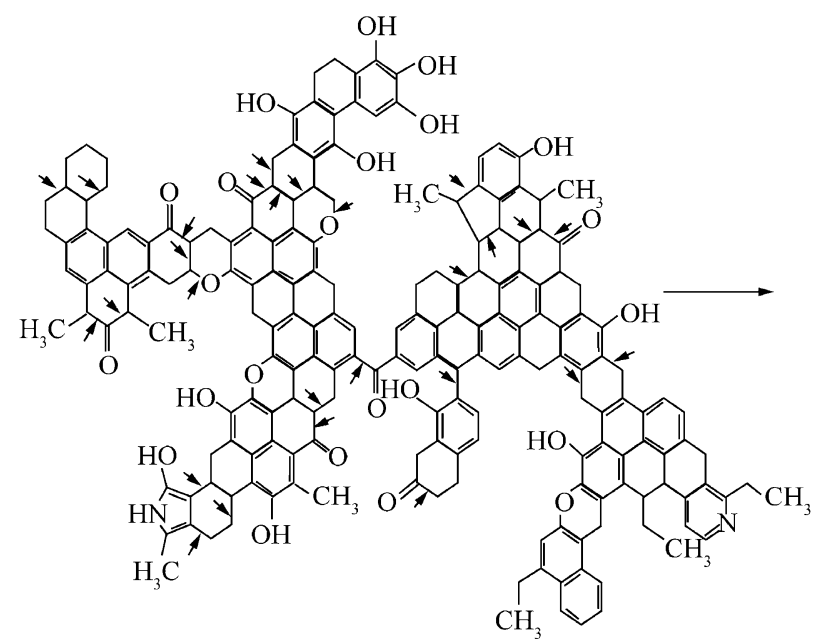

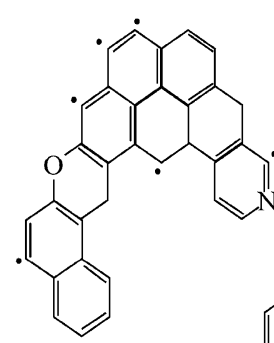<smiles>C=C=NC=C1CCc2ccccc2-c2ccccc21</smiles><smiles>C1=CCCC=C1</smiles>

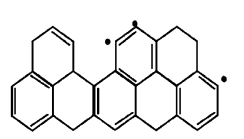<smiles>c1cc[nH]c1</smiles>

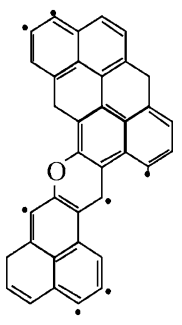<smiles>c1ccc2ccccc2c1</smiles>

Fig. 12 Diagram on SDV active sites during the pyrolysis and the pyrolysis process 
Table 9 Inertinite bond order distribution

\begin{tabular}{|c|c|c|c|c|c|}
\hline $\begin{array}{l}\text { Bond } \\
\text { name }\end{array}$ & $\begin{array}{l}\text { Bond } \\
\text { order }\end{array}$ & $\begin{array}{l}\text { Bond } \\
\text { name }\end{array}$ & $\begin{array}{l}\text { Bond } \\
\text { order }\end{array}$ & $\begin{array}{l}\text { Bond } \\
\text { name }\end{array}$ & $\begin{array}{l}\text { Bond } \\
\text { order }\end{array}$ \\
\hline 105-C97 & 922 & C8-C6 & 1.036 & C191-C189 & 1.28 \\
\hline $160-\mathrm{C} 4$ & 926 & C168-C130 & 1.038 & $\mathrm{C} 46-\mathrm{C} 45$ & 1.28 \\
\hline $28-\mathrm{O} 221$ & 932 & C117-C90 & 1.039 & C152-C150 & 1.28 \\
\hline 79-C117 & 933 & O157-C52 & 1.051 & $\mathrm{C} 14-\mathrm{C} 11$ & 1.28 \\
\hline 9-C8 & 942 & C10-C7 & 1.054 & C53-C52 & 1.28 \\
\hline O160-C77 & 942 & C85-C98 & 1.077 & C181-C179 & 1.28 \\
\hline $54-\mathrm{C} 22$ & 953 & $\mathrm{C} 25-\mathrm{C} 23$ & 1.080 & C71-C69 & 1.29 \\
\hline $55-\mathrm{C} 74$ & 956 & C15-C14 & 1.081 & C63-C62 & 1.29 \\
\hline C79-C78 & 956 & C34-C45 & 1.084 & C114-C112 & 1.29 \\
\hline C153-C132 & 0.963 & $\mathrm{C} 43-\mathrm{C} 27$ & 1.089 & $\mathrm{C} 83-\mathrm{C} 82$ & 1.29 \\
\hline C176-C174 & 0.965 & O120-C95 & 1.089 & C145-C152 & 1.29 \\
\hline $\mathrm{O} 125-\mathrm{C} 122$ & 0.968 & C76-C60 & 1.089 & C51-C33 & 1.30 \\
\hline C109-C108 & 0.968 & C29-C27 & 1.116 & C46-C48 & 1.30 \\
\hline C55-C54 & 0.969 & C33-C31 & 1.118 & C144-C151 & 1.30 \\
\hline O221-C68 & 0.969 & $\mathrm{O} 184-\mathrm{C} 172$ & & C94-C102 & 1.30 \\
\hline O124-C69 & 0.973 & $\mathrm{C} 56-\mathrm{C} 24$ & & $\mathrm{C} 31-\mathrm{C} 40$ & 1.30 \\
\hline C175-C174 & 0.975 & C94-C92 & & C138-C123 & 1.30 \\
\hline C178-C175 & & $\mathrm{C} 179-\mathrm{C}$ & & C75-C74 & 1.30 \\
\hline O125-C61 & & & & C141-C139 & $1.30 \mathrm{~s}$ \\
\hline $\mathrm{C} 24-\mathrm{C} 22$ & & & & & 1.313 \\
\hline C138-C154 & & & & & 1.31 \\
\hline C154-C112 & 0.979 & & & & 1.31 \\
\hline C73-C70 & & & & & 1.321 \\
\hline $59-C 5$ & & C194 & & & 1.322 \\
\hline $55-\mathrm{C} 57$ & & & & $-\mathrm{C} 141$ & 1.323 \\
\hline $104-\mathrm{C} 103$ & 0.982 & C95-C & & & 1.325 \\
\hline $1-\mathrm{C} 9$ & .982 & & & & 1.325 \\
\hline C75-C73 & 982 & C82-C115 & 1.158 & C138-C137 & 1.325 \\
\hline C26-C44 & 984 & $\mathrm{C} 28-\mathrm{C} 25$ & & & 1.326 \\
\hline C108-C127 & 984 & $\mathrm{C} 1$ & & & 1.327 \\
\hline 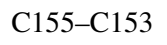 & & & & & 1.53 \\
\hline $\mathrm{C} 123-\mathrm{C} 121$ & & & & & 1.337 \\
\hline C106-O105 & & & & & 1.33 \\
\hline $\mathrm{C} 121-\mathrm{C} 113$ & 0.988 & C145-C144 & & 73-C171 & 1.338 \\
\hline C177-C176 & 0.989 & C189-C187 & & 39-C75 & 1.34 \\
\hline C121-C63 & 0.990 & 70-C180 & & & 1.34 \\
\hline $\mathrm{O} 219-\mathrm{C} 213$ & 0.990 & C131-N129 & & 69-C68 & 1.34 \\
\hline C134-C147 & 0.992 & & & C201-C199 & 1.34 \\
\hline C154-C153 & 0.994 & $\mathrm{C} 171-\mathrm{C} 170$ & & C111-C113 & 1.350 \\
\hline C166-C44 & 0.994 & C191-C190 & & & 1.350 \\
\hline C44-C158 & 0.996 & C188-C186 & 1.194 & 48-C47 & 1.35 \\
\hline C110-C100 & 0.996 & & & C122-C123 & $1.35 \mathrm{c}$ \\
\hline C139-C126 & 0.996 & C210-C149 & 1.195 & C63-C61 & $1.35 \mathrm{c}$ \\
\hline C108-C99 & 0.996 & C86-C84 & 1.197 & C50-C49 & 1.360 \\
\hline C126-C64 & 0.996 & C36-C35 & 1.200 & $\mathrm{C} 81-\mathrm{C} 80$ & 1.361 \\
\hline C204-C198 & 0.996 & C58-C66 & 1.201 & C136-C135 & 1.361 \\
\hline C133-C132 & & $\mathrm{C} 4-\mathrm{C} 2$ & 1.202 & C137-C136 & 1.36 \\
\hline C209-C196 & 0.997 & C84-C82 & 1.212 & C101-C99 & 1.371 \\
\hline
\end{tabular}

Table 9 continued

\begin{tabular}{|c|c|c|c|c|c|}
\hline $\begin{array}{l}\text { Bond } \\
\text { name }\end{array}$ & $\begin{array}{l}\text { Bond } \\
\text { order }\end{array}$ & $\begin{array}{l}\text { Bond } \\
\text { name }\end{array}$ & $\begin{array}{l}\text { Bond } \\
\text { order }\end{array}$ & $\begin{array}{l}\text { Bond } \\
\text { name }\end{array}$ & $\begin{array}{l}\text { Bond } \\
\text { order }\end{array}$ \\
\hline C132-C116 & 0.997 & C127-C130 & 1.213 & C41-C39 & 1.374 \\
\hline C78-C111 & 0.998 & C59-C58 & 1.213 & C196-C202 & 1.375 \\
\hline C216-C215 & 0.999 & C88-C114 & 1.214 & C39-C38 & 1.380 \\
\hline C106-C104 & 0.999 & C195-C193 & 1.214 & C36-C34 & 1.392 \\
\hline C21-C20 & 1.000 & C187-C186 & 1.214 & C213-C210 & 1.393 \\
\hline C109-C83 & 1.000 & C60-C58 & 1.214 & C66-C64 & 1.399 \\
\hline C135-C161 & 1.001 & C7-C5 & 1.215 & $\mathrm{C} 18-\mathrm{C} 17$ & 1.401 \\
\hline C78-C62 & 1.001 & C195-C194 & 1.216 & $\mathrm{C} 130-\mathrm{C} 128$ & 1.410 \\
\hline C215-C48 & 1.002 & C146-C145 & 1.218 & C97-C95 & 1.410 \\
\hline C206-C192 & 1.002 & C93-C101 & 1.219 & C5-C4 & 1.411 \\
\hline C212-C137 & 1.002 & C148-C147 & 1.219 & C49-C47 & 1.411 \\
\hline C207-C197 & 1.002 & $\mathrm{C} 43-\mathrm{C} 35$ & 1.219 & C81-C103 & 1.412 \\
\hline C159-C76 & 1.003 & C61-C59 & 1.220 & C197-C203 & 1.413 \\
\hline C174-C188 & 1.003 & O185-C181 & 1.220 & C199-C198 & 1.417 \\
\hline C1-C87 & 1.004 & C214-C213 & 1.220 & $\mathrm{C} 18-\mathrm{C} 16$ & 1.418 \\
\hline C20-C22 & 1.004 & C65-C64 & 1.227 & C67-C65 & 1.424 \\
\hline C209-C176 & 1.004 & C96-C94 & 1.227 & $\mathrm{C} 25-\mathrm{C} 24$ & 1.430 \\
\hline C72-C71 & 1.005 & C59-C67 & 1.231 & C190-C188 & 1.430 \\
\hline $\mathrm{C} 1-\mathrm{C} 110$ & 1.006 & C89-C88 & 1.231 & C40-C38 & 1.431 \\
\hline C158-C53 & 1.007 & C91-C86 & 1.233 & N140-C74 & 1.438 \\
\hline C155-C151 & 1.007 & C35-C33 & 1.235 & C147-C133 & 1.450 \\
\hline C29-C37 & 1.007 & C84-C88 & 1.236 & C80-C102 & 1.454 \\
\hline C218-C214 & 1.008 & C32-C41 & 1.241 & C27-C26 & 1.454 \\
\hline C205-C202 & 1.009 & $\mathrm{C} 50-\mathrm{C} 45$ & 1.244 & C91-C90 & 1.455 \\
\hline C79-C77 & 1.010 & C198-C194 & 1.245 & C142-N140 & 1.455 \\
\hline C168-C101 & 1.011 & C32-C31 & 1.248 & $\mathrm{C} 23-\mathrm{C} 21$ & 1.461 \\
\hline C67-C72 & 1.011 & C68-C56 & 1.248 & C214-C211 & 1.463 \\
\hline C134-C115 & 1.011 & C186-C196 & 1.249 & C201-C200 & 1.470 \\
\hline C73-C65 & 1.011 & C187-C197 & 1.249 & C116-C115 & 1.484 \\
\hline C12-C9 & 1.012 & C103-C96 & 1.249 & C180-C177 & 1.491 \\
\hline C166-C30 & 1.012 & C93-C92 & 1.250 & C127-C131 & 1.493 \\
\hline C167-C51 & 1.013 & C99-C98 & 1.250 & C193-C192 & 1.494 \\
\hline C37-C36 & 1.013 & C211-C150 & 1.251 & C29-C28 & 1.500 \\
\hline C21-C30 & 1.014 & C128-N129 & 1.254 & C148-C146 & 1.563 \\
\hline C13-C12 & 1.016 & $\mathrm{C} 2-\mathrm{C} 172$ & 1.259 & $\mathrm{O} 182-\mathrm{C} 178$ & 1.576 \\
\hline C208-C190 & 1.020 & $\mathrm{C} 135-\mathrm{C} 122$ & 1.265 & C76-C77 & 1.589 \\
\hline C183-C180 & 1.021 & C172-C170 & 1.267 & C15-C13 & 1.768 \\
\hline C42-C41 & 1.023 & C85-C83 & 1.270 & O156-C42 & 1.802 \\
\hline C164-C152 & 1.029 & C87-C86 & 1.271 & O169-C168 & 1.812 \\
\hline C50-C42 & 1.032 & C57-C56 & 1.273 & O118-C117 & 1.839 \\
\hline O143-C141 & 1.034 & C200-C195 & 1.274 & O162-C161 & 1.847 \\
\hline O217-C46 & 1.035 & C92-C100 & 1.275 & O19-C8 & 1.858 \\
\hline $\mathrm{O} 220-\mathrm{C} 210$ & 1.035 & C111-C89 & 1.277 & O119-C54 & 1.945 \\
\hline O165-C66 & 1.035 & C151-C149 & 1.285 & O107-C106 & 1.956 \\
\hline
\end{tabular}

Autoclave heating rate remained at $8{ }^{\circ} \mathrm{C} / \mathrm{min}$, and the temperature was kept constant when it reached $455^{\circ} \mathrm{C}$. The results are shown in Table 10. 


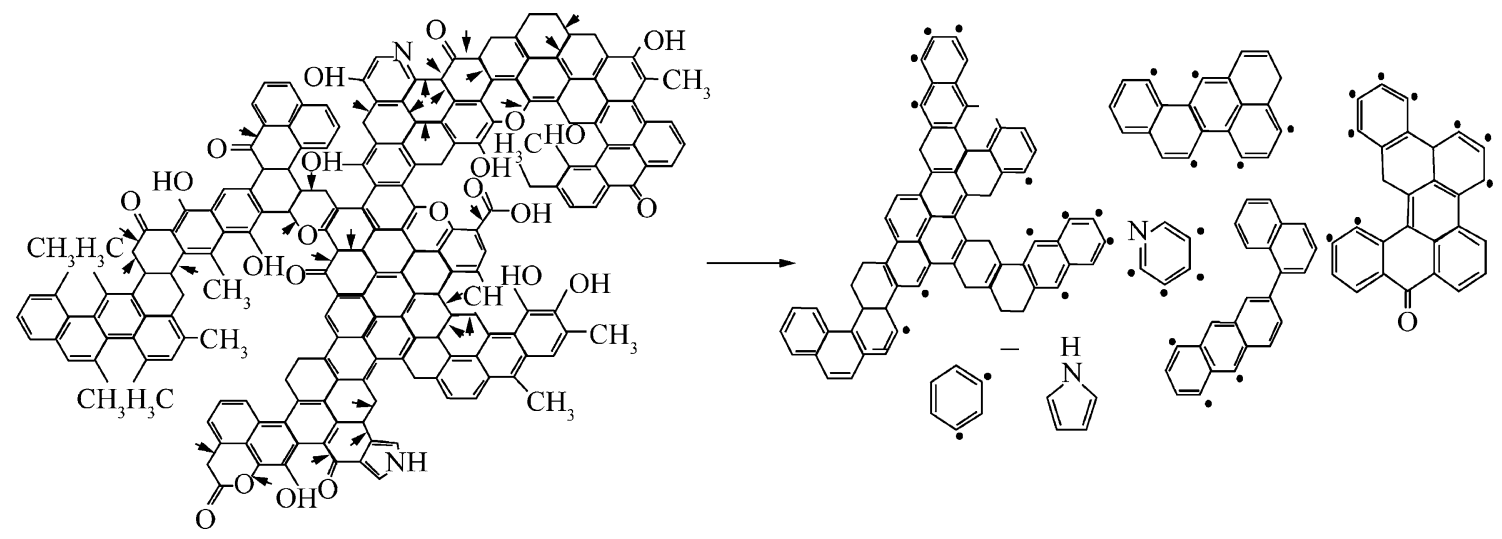

Fig. 13 Diagram on SDI active sites during the pyrolysis and the pyrolysis process

Table 10 Shenhua coal maceral liquefaction experiment results

\begin{tabular}{|c|c|c|c|c|c|c|c|c|}
\hline \multirow[t]{2}{*}{ Reaction time (min) } & \multicolumn{4}{|l|}{ SDI } & \multicolumn{4}{|l|}{ SDV } \\
\hline & Oil yield (\%) & Difference & Gas yield (\%) & Difference & Oil yield (\%) & Difference & Gas yield $(\%)$ & Difference \\
\hline 0 & 43.03 & & 7.45 & & 61.55 & & 6.51 & \\
\hline 30 & 51.32 & 8.29 & 9.51 & 2.06 & 73.16 & 11.61 & 9.01 & 2.50 \\
\hline 60 & 58.95 & 7.63 & 10.76 & 1.25 & 74.05 & 0.89 & 12.95 & 3.94 \\
\hline
\end{tabular}

As can be seen from Table 10, when it reaches the reaction temperature with a constant heating rate, i.e. the reaction time is "0", SDI oil yield (hexane solubles) is $43.03 \%$, rate of gasification is $7.45 \%$; in the same conditions, SDV oil yield goes up to $61.55 \%, 18.52 \%$ points higher than SDI, which indicates that small molecule structure are dominant in the molecular structure of SDV, and most of its pyrolysis products are small-molecule ones.

At the initial stage of the reaction, when the reaction is at its $30 \mathrm{~min}$, SDI oil yield improves by $8.29 \%$, rate of gasification by $2.09 \%$; while for SDV within the same amount of time, the oil yield increases by $11.61 \%$, and rate of gasification is equal to that of SDI. The reason behind this is there is mainly pyrolysis happening in the initial stage of the reaction, i.e. the pyrolysis process which has not been finished in the heating process will continue in this stage. This experiment also shows that SDV is dominated by small molecule structure and its liquefaction is subject to thermodynamics control.

In the middle and late stage of the reaction, between 30 and $60 \mathrm{~min}$ of the reaction time, SDI oil yield improves by $7.63 \%$, reaching nearly $59 \%$, while rate of gasification increases only by $1.25 \%$; meanwhile, SDV oil yield increases only by $0.89 \%$, while rate of gasification is up $3.94 \%$, much higher than that of SDI.

The experiment results further demonstrate that SDI pyrolysis products have large molecular weights; the way to improve the yield rate of its liquefaction is therefore to increase the hydrocracking activity and severity of its macromolecule products. SDI liquefaction process is subject to dynamics control. On the other hand, SDV pyrolysis products have small molecular weights; the target products will have secondary pyrolysis and rate of gasification increases as reaction time and severity increases.

\subsection{Efficient directional direct coal liquefaction} technology fit for the macerals characteristics of Shenhua coal

Through bond order parameter analysis of molecular structure of SDV and SDI and with results of autoclave hydrogenation liquefaction experiment, the research has proved that liquefaction mechanisms of SDV and SDI are different.

As vitrinite and inertinite have different liquefaction mechanisms, and different products come from different processes, so there will inevitably be increase of gas yield if general direct coal liquefaction process is applied to Shenhua coal, which has a high content of inertinite.

Process that suits the macerals characteristics of Shenhua coal should be as follows: For vitrinite, a shorter reaction time is appropriate; reaction mechanism is mainly pyrolysis; there must be adequate active hydrogen to prevent the condensation of radical fragments of small molecules produced by pyrolysis. As regards inertinite, it requires longer reaction time and higher severity of the reaction, and the reaction mechanism is mainly hydrocracking, hence the need for high-activity catalysts and high-activity hydrogen-donating solvents. 
Table 11 Results of a comparative test on common process and Shenhua process applied on Shenhua coal

\begin{tabular}{lll}
\hline Project & Foreign process & Shenhua process \\
\hline$P(\mathrm{MPa})$ & 19 & 19 \\
$T\left({ }^{\circ} \mathrm{C}\right)$ & 455 & 455 \\
Conversion rate $(\%)$ & 89.69 & 91.22 \\
Product yield $(\%)$ & & \\
Gas generated $(\%)$ & 17.89 & 13.11 \\
Oil products $(\%)$ & 52.56 & 57.42 \\
\hline
\end{tabular}

If vitrinite and inertinite of Shenhua coal can be separated respectively and the subsequent two hydrogenation processes be set, one for vitrinite, the other for inertinite, then the problem of high rate of gasification caused by different reaction mechanisms of vitrinite and inertinite can be properly addressed. But it is industrially impossible.

Process that suits the maceral characteristics of Shenhua coal is to control the reaction time of SDV and SDI in the same reaction system to avoid secondary pyrolysis of SDV light products.

Shenhua direct coal liquefaction process is bespoke developed on the basis of the maceral characteristics of Shenhua coal. It sets a gas-liquid separator in the upper part of the reactor, thus light oils produced from one-way pyrolysis of vitrinite can be separated in time at the top of the reactor to prevent secondary pyrolysis thanks to short one-way reaction time of forced circulation reactor. Macromolecule fragments produced from inertinite pyrolysis will again be put into the reactor by circulating pump for catalytic hydrogenation in order to obtain more liquid products. The whole process realized efficient, directional, and effective conversion of the vitrinite and inertinite of Shenhua coal.

Under the same reaction conditions, the research conducted a comparative test on Shenhua coal with a small $0.12 \mathrm{t} / \mathrm{d}$ direct coal liquefaction continuous unit (BSU). The results are shown in Table 11, and the data of which clearly demonstrates that gas yield of Shenhua process is significantly lower than that of foreign process as Shenhua process avoids the secondary pyrolysis of generated oil, hence a significantly higher oil yield compared to that of foreign process; meanwhile, Shenhua process extends the reaction time of heavy oil and bitumen whilst avoiding the secondary pyrolysis of generated oil, so the conversion rate of Shenhua process is higher than that of foreign process.

\section{Conclusions}

(1) From the constructed SDV and SDI molecular structure models, it can be seen that SDV is largely made of small molecules, while SDI is made of macromolecules.

(2) According to data about SDV and SDI molecular model bond order, bond length and electronic layouts number, they are significantly different during pyrolysis, bond breaking points of SDV are far more than that of SDI; SDV releases through pyrolysis large amounts of small molecule hydrocarbons with its macromolecular structure basically being destroyed, while SDI doesn't release through pyrolysis so much small molecules as fragments with larger molecular weights.

(3) Findings of the autoclave experiment show that SDI pyrolysis products have large molecular weights. The way to improve the yield of its liquefaction is to increase hydrocracking activity and severity of its macromolecule products. SDI liquefaction process is subject to dynamics control. Since the molecular weights of SDV pyrolysis products are relatively small, the target products will have secondary pyrolysis as reaction time and severity increases, leading to a consequent increase in gas yield. Vitrinite liquefaction can be categorized as the process of thermodynamics control.

(4) Shenhua direct coal liquefaction process that is developed on the basis of the maceral characteristics of Shenhua coal can effectively reduce its gas yield and improve oil yield.

Acknowledgments Supported by the National Engineering Laboratory of Direct Coal Liquefaction (MZY-16).

Open Access This article is distributed under the terms of the Creative Commons Attribution License which permits any use, distribution, and reproduction in any medium, provided the original author(s) and the source are credited.

\section{References}

Lin HL, Li KJ, Zhang XW, Li YL (2013a) Study on Shendong Shangwan coal and the structure characteristics of its maceral concentrates. Coal Convers 36(2):1-5

Lin HL, Li KJ, Zhang XW (2013b) Structural characteristics and model constructing of inertinite concentrates of Shangwan coal. J Fuel Chem Technol 41(6):641-648

Shu GP (2009) History and significance of the development of Shenhua coal direct liquefaction process. Shenhua Sci Technol 27(1):78-82

Shu GP, Xu ZG (1997) Direct coal liquefaction technology. Chin Coal 10:21-24

Shu GP, Shi ShD, Li KJ (2003) Coal liquefaction technology. Coal Industry Press, Beijing, pp 97-98 